\title{
The architecture of strategic management of innovative development of companies in the digital economy
}

\author{
Oleg Burgonov ${ }^{1}$, Natalya Golubetskaya ${ }^{1}$, Elena Ushakova $^{1}$, and Tamara Chirkova $^{1 *}$ \\ ${ }^{1}$ Saint-Petersburg University of Management Technologies and Economics, Lermontovskiy avenue, \\ 44, St Petersburg, 190103, Russia
}

\begin{abstract}
The paper discusses the development of the methodological apparatus of strategic management of innovative development in terms of the development of algorithms for the architecture of the company in the digital economy. In particular, an approach to the development of the architecture of a system for managing innovative development of companies is proposed, taking into account the positioning and effectiveness of the business and the socio-economic effect of its functioning at the regional level. The analysis of Russian enterprises is carried out, and the elements of business transformation under the influence of digital technologies are considered. Based on the results, scientists and practitioners can develop specific recommendations for managing innovative companies using digital technologies aimed at gaining competitive advantages and creating a new business design.
\end{abstract}

\section{Introduction}

The digital economy has become a tool for the development of global socio-economic systems. The use of intellectual capital made it possible to transform the functions of material production, which created the conditions for the stable functioning of business in the global market. In the works of A. Sundararajan and M. Cohen, it was shown that digital technologies made it possible to optimize management systems in companies with powerful innovative potential [1]. Acs Z.J., Estrin S., Mickiewicz T. predict scenarios of socioeconomic development of the global economy. At the same time, institutional transformations under the influence of knowledge and skills play a significant role. A special place is given to network and production platforms that unite creative companies. In this system, monitoring and assessment of performance is carried out by customers, management decisions are adjusted according to their preferences [2].

The purpose of this study is to analyze the impact of the digital economy on the architecture of strategic management of innovative development of companies. The tasks are: analysis of the evolution of approaches to managing the innovative development of

* Corresponding author: natalya_golubeck@mail.ru 
companies in the digital economy; characterization of strategic guidelines for creating architecture under the influence of economic and institutional transformations that contribute to the optimization of the value chain; determination of the areas of management transformation under the influence of digital technologies.

The literature has a large number of interpretations of the concept of "innovation management". Most authors define this category as a way of interpreting the system of views or the design of scenarios of companies based on intellectual capital. In this paper, innovation management is understood as a system of views, laws, principles, approaches, and judgments that determine options for the functioning of companies, which allow them to become leaders in the global market. The conditions and factors that ensure the synchronization of the strategy, business processes and organizational structure of the company in a rapidly changing external environment caused by the development of digital technologies are considered as a management architecture.

The digital economy transforms the organizational forms and management systems of innovative companies. In the organizational structure, R. Drucker singled out the functions of workers who form intellectual capital; administrators who regulate knowledge and skills; scientific researchers; entrepreneurs engaged in the process of bringing knowledge to the final result [3]. In the global market, the importance of government programs for implementing the tasks of the digital society is being strengthened, taking into account the government remained the key stakeholder and maintaining active relations [4]. Doran J., McCarthy N., O'Connor M. emphasize that guidelines for strategic management of companies are aimed at creating economic and institutional conditions conducive to optimizing their activities on the basis of digital technologies [5].

B. Jaruzelski, R. Holman, studying innovative firms, drew attention to the strengthening of their own key success factors due to nodal technological competencies. The value chain includes manufacturers, suppliers, partners. Moreover, the life cycle of innovation activity is reduced due to corporate networks in the field of research and development in the virtual information space [6].

One of the strategic goals of innovative companies is to optimize the management system. A review of the scientific literature indicates several approaches to the category of "innovative development" and its impact on the adjustment of the company's strategy. K. Konrad [7] considers innovation processes as a strategic tool that guarantees the stable functioning of the company and increasing investment potential. According to the approach of $\mathrm{G}$. Westerman, the competitive advantages of companies are supported by its innovative potential [8].

According to F. Cosenz and G. Noto, the application of new venture strategies is a source of increasing the effectiveness of innovation [9]. Selloni D. proves by examples that new forms of economy (sharing economy, collaborative consumption, peer-to-peer economy) form the priorities of innovation [10]. K. Lobacz, P. Glodek study the impact of innovative development on management of changes in a company [11]. Most authors conclude that innovation, as a factor in optimizing the management system, allows creating the conditions for a flexible company architecture under the influence of digital technologies [12].

In this paper, strategic management of innovative development of companies is understood as an economic category that characterizes a process that contributes to the real and potential superiority of a business structure in stable operation in a dynamic competitive environment in order to increase consumer demand, the ability to produce and sell a competitive product by improving quality and domination in the market. 


\section{Methodology and theory}

A comprehensive analysis of the strategic management architecture of innovative companies is necessary to identify potential resources for improving competitiveness. The digital economy has changed the role of leaders in the global market. Large companies have powerful investment resources that are aimed at implementing structural transformations in the movement of capital. The volume of investments directed to global innovation projects is growing.

Consortia and integration interstate associations are cooperative organizational forms of optimizing the architecture of strategic management. The companies are guided by technological segments of the global economy, in which growth of mass consumer demand is forecasted. Business models of storing giant arrays of information data, cloud technologies, Internet games, electronic commerce, intellectual capital and virtual information space led to increased competition [13].

Kadyrova O.V., Ksenofontova T.Y., Smirnov R.V. analyze the strategic goals of managing organizations using the digital economy using the example of companies in various segments of the economy. The components of the management strategy in business structures are: priority support for the digital technology infrastructure; mass sales of products using Internet channels; functioning in virtual space [14].

Priorities in the development of companies are determined on the basis of a comprehensive analysis of indicators compared with global market leaders. Global digital technologies have identified priorities in the segment of informatization, public education, provision of public services and Internet commerce. The information array, its processing speed, intellectual capital and innovative potential have become objects of production and consumption in the global economy.

In modern conditions, the integration infrastructure of the digital space is being formed, which dictates the requirements for the architecture of business structures in accordance with the strategy of economic modernization. Digital platforms used in various types of activities, cloud Internet services, artificial intelligence, wireless communications and virtualization of development scenarios will increase the efficiency of management decisions.

Sundararajan A. considers the strategy of innovative development of companies in a rapidly changing external environment. In the global market, there has been a decline in employment and support for populist theories of national capitalism [15]. The integrated management system of organizations uses design methods, special-purpose method, resource and traditional approaches based on the development of a tree of objectives [16]. In the works of Sipos-Gug S., Badulescu A., much attention is paid to macroeconomic factors that transform the organizational forms of innovative development [17].

B. Jaruzelski, R. Holman formulated the principles of developing a strategy for managing companies that should become leaders in innovation: systematic activities to support innovative potential; clear goal and objectives; priority of the innovation vector; concentration of resources for breakthrough innovations; integration with all market players. Leading companies in Europe and the USA (more than $40 \%$ of respondents) pay special attention to developing a long-term innovation strategy. At the same time, $80 \%$ of top managers believe that the importance of an effective innovation strategy has increased the competitive advantages of their company [6].

To adjust the management strategy, it is necessary to calculate the integral indicator of the company's innovative potential, which is formed on the basis of a comprehensive assessment of all particular parameters. Priority areas of architecture formed in the business structure are determined taking into account the range of products and provided services, which are formed on the basis of an assessment of investment opportunities. 
Research and development work, production chain and marketing research determine the areas of adjusting the company's management strategy. An assessment of the conditions and factors of the organization's progressive development can be carried out taking into account material and technical capabilities on the basis of a balance of financial, production indicators, and human capital assessment. Organizational changes and managerial innovations in companies should reflect the development trends of digital technologies [18].

The strategy for managing innovative development of companies is being transformed taking into account a comprehensive analysis of factors and conditions for the functioning of a business structure. To optimize the architecture of the company, it is necessary to assess the innovative potential, the optimization priorities of the information and methodological support of innovative projects in accordance with international norms and standards of quality $[16 ; 19-26]$.

The adjustment of the management strategy of innovative companies is carried out in stages based on the optimization of management decisions and management. For a visual representation of the mechanism for managing the innovative development of the organization, we present an algorithm for developing management decisions of the company in the form of a flowchart. The flowchart of the company's innovative development management is presented in Fig. 1.

In this regard, an approach is proposed that, along with the factors considered in traditional approaches, takes into account time management, information support, quality parameters, and management decisions related to changes in the company. Moreover, the innovative potential is assessed on the basis of the parameters of intellectual and human capital, the presence of patents, investment resources, know-how in advanced technologies, personnel qualifications, etc.

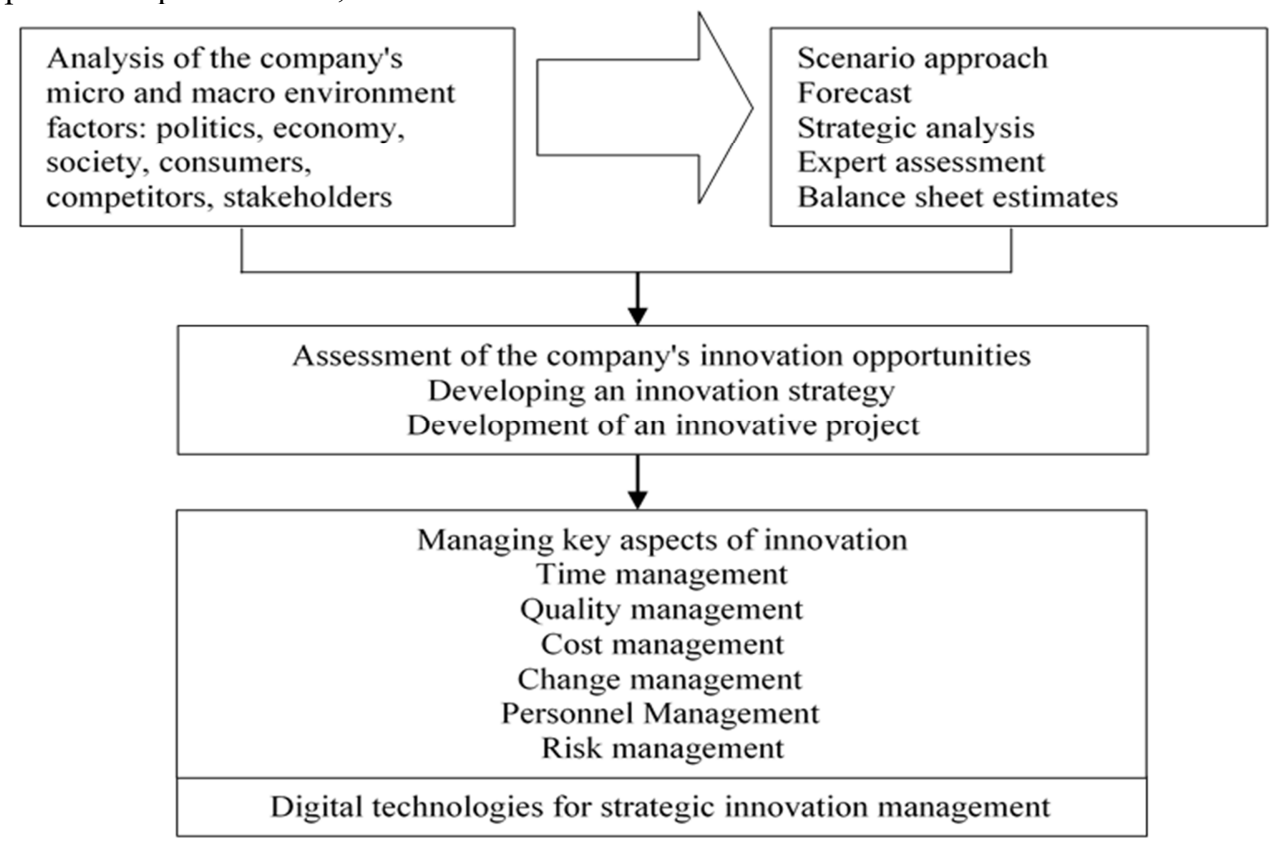

Fig. 1. Architecture of managing a company's innovation development strategy in the digital economy 


\section{Results}

The study examined more than 500 companies in St. Petersburg, which have various sizes, types of activities and forms of ownership due to the use of digital technologies and their impact on the architecture of strategic innovation management. In the course of a comprehensive analysis, the following blocks of business models were assessed:

- key elements of enterprise architecture and organizational structure, taking into account the use of digital technologies;

- promising business strategy and mission that ensures sustainable operation and competitive advantages;

- development of scenarios for expanding the range of innovative products and services;

- $\quad$ synchronization of elements of business architecture and digital technologies;

- reduction of operational and technological risks, increasing the effectiveness of control functions.

Most Russian companies use architectural methods based on the implementation of IT applications and the transformation of the organizational structure in order to optimize it. The increasing importance of digital technologies has led to the dependence of the company's performance on the level of security and the quality of the parameters of the information and analytical infrastructure.

As a result of the study, the frequency of organizational changes in the architecture of company management using technologies of the digital economy was established (Fig. 2).

Once every five years or less

Every two to four years

Once a year and more often

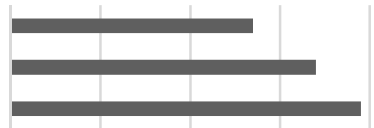

$\begin{array}{llllll}0 & 10 & 20 & 30 & 40 & 50\end{array}$

Fig. 2. Organizational changes in the structure of company management using technologies of the digital economy

The development of the strategy management architecture of most Russian innovative companies lags significantly behind the speed of transformation in the organizational structure of leaders. Digital technologies used in architecture had a positive impact on quality management parameters in $72 \%$ of companies. Information and communication technologies have made it possible to optimize the budgeting procedure and attract additional investment in more than $60 \%$ of enterprises. Information platforms, cloud-based Internet services, networking, and virtual space have made it possible to increase the efficiency of management decisions in more than $30 \%$ of companies (Fig. 3).

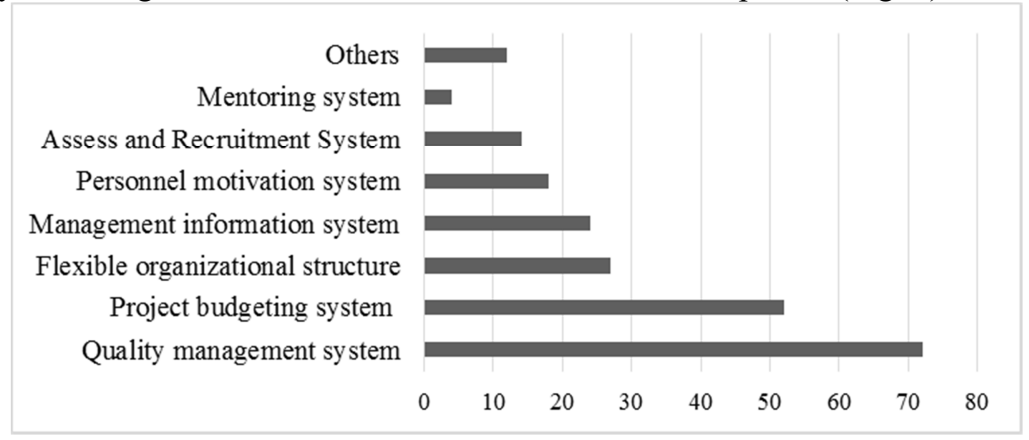

Fig. 3. The impact of digital technology on priority areas in forming the architecture of innovative activities of companies (2018) 
The architecture of the strategy management of innovative companies requires the presence and constant flexible changes in the blocks reflecting the parameters of the information and analytical system, quality management, budgeting process, formation and motivation of human capital. Leading companies, when changing their architecture, use the technology of parametric modeling of operational activities. When implementing innovative projects, managers use visualization tools for information and analytical databases in a scenario-based approach.

Large companies in Russia are leaders in the formation and processing of centralized information databases. They use the on - line mode for flexible restructuring and adjusting development scenarios. Under the influence of digital technologies, Russian companies have accelerated organizational structural transformations in architecture. Flexible restructuring is carried out by companies at least once every two to three years, taking into account digital technologies (Fig. 4).

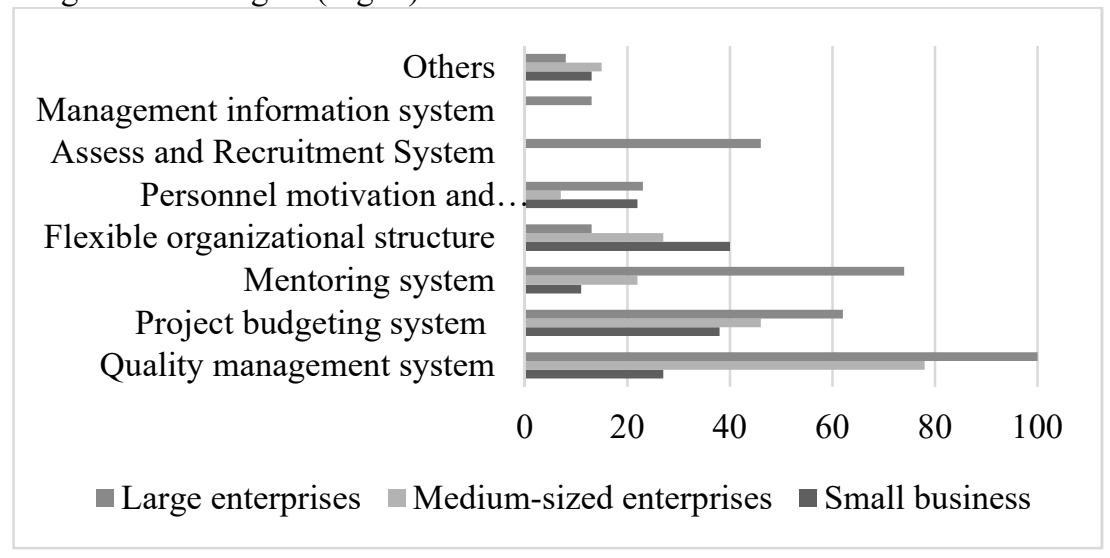

Fig. 4. The use of digital technologies in the formation of architecture of companies that are different in the scale of activity

The architecture of the strategy for managing the innovative development of firms and the selection of adequate components and methods for its implementation have a decisive effect on the competitiveness and life cycle of the enterprise. Changing the company's architecture in response to shocks and environmental traps should be urgent, often asymmetric to an increase in entropy and environmental uncertainty, aimed at increasing the use of digital technologies in management and increasing the level of personnel competence.

\section{Discussion}

Information resources, network access to them by users within the information fund, telecommunication computing system, and intellectual capital, which allow using modern methods and algorithms for the development and implementation of management decisions, are fundamental factors in the digital economy. Under the influence of digital technologies, new criteria for the competitiveness of companies are formed, which involve the intensive use of human capital, knowledge and skills.

At the regional level of management, structural restructuring of the economy is underway, under the influence of which business models of innovative development of companies are changing. In essence, we are talking about the formation of the integration infrastructure of the digital space for the economic entities of the region.

In this case, such technologies as digital platforms for various industry segments, cloud 
Internet services, information and analytical systems, artificial intelligence, methods for supporting management decisions, technical means of information interaction based on wireless communications and virtualization of development scenarios taking into account external and internal risks should be used.

\section{Conclusions}

The formation of the architecture for managing the strategy of innovative development of companies in the digital economy is aimed at increasing the speed of adaptation to ongoing changes in the external and internal environment. Coordination and control of transformation across the organization requires adjusting the strategy and goals changing the business process and the direction of priority projects. At the same time, changes in the organizational structure occur, which are reflected in the knowledge and authority in the company under the influence of information flows. The management architecture should provide the solution to the following tasks at all levels:

- adaptability and flexibility of the organizational structure to changes in digital technologies;

- $\quad$ optimization of network cooperation of all entities;

- $\quad$ presence of investment potential, which allows diversifying areas of activity;

- $\quad$ support and development of human capital and a high professional level of personnel;

- formation of a portfolio of promising projects;

- $\quad$ availability of reserves to enhance competitiveness in the global market for goods and services.

The competitive advantages of companies are the professional level and experience in this segment, the possibility of horizontal diversification of activities, the development and implementation of a quality management system, an active marketing policy in the program of long-term strategic development. Digital platforms are the foundation for optimizing decisions developed and implemented in the management system, identifying trends and development priorities of innovative activities.

\section{References}

1. M. Cohen, A. Sundararajan. University of Chicago Law Review Online, 82, 116-133 (2017)

2. Z. Acs, S. Estrin, T. Mickiewicz, etc. Small Business Economics, 51(2), 501-514 (2018)

3. P. Drucker. Post-capitalist society, 204 (1993)

4. Q. Thao Dang, P. Jasovska, H. Rammal. Journal of World Business, 55(1), (2020) DOI: $10.1016 /$ j.jwb.2019.101042

5. J. Doran, N. Doran, M. O’Connor. Cogent Economics \& Finance, 6, 1442093 (2018) DOI: $10.1080 / 23322039.2018 .1442093$

6. B. Jaruzelski, R. Holman, Strategy\&Business, 05, (2011)

7. K. Konrad, K. Böhleb. Futures, 109, 101-107 (2019) DOI: 10.1016/j.futures.2019.03.003

8. Digital Transformation: A Road Map for Billion-Dollar Organizations. MIT Center for Digital Business and Capgemini Consulting, 68 (2011)

9. F. Cosenz, G. Noto. Long Range Planning, 51(1), 127-140 (2018) DOI: 10.1016/j.lrp.2017.07.001 
10. D. Selloni. CoDesign for Public-Interest Services, 177-189 (2017) DOI: 10.1007/9783-319-53243-1_11

11. K. Łobacz, P. Głodek. Procedia Economics and Finance, 23, 487-494 (2015) DOI: 10.1016/S2212-5671(15)00353-6

12. M. Edwards-Schachter. International Journal of Innovation Studies, 2(2), 65-79 2018 DOI: $10.1016 /$ j.ijis.2018.08.004

13. A. Ustundag, E. Cevikcan. Industry 4.0: Managing. The Digital Transformation. 293 (2017)

14. O. Kadyrova, T. Ksenofontova, R. Smirnov, etc. IJRTE, 8(2), 4302-4305 (2019) DOI: 10.35940/ijrte.B2821.078219

15. A. Sundararajan. The sharing economy. The end of employment and the rise of crowdbased capitalism, 256 (2016)

16. ISO/TR 10006: 1997 (E). Quality Management - Guidelines to quality in project management

17. S. Sipos-Gug, A. Badulescu. Annals of Faculty of Economics, 1, 601-611 (2015)

18. N. Golubetskaya, T. Kosheleva, V. Kunin. IOP Conference Series: Earth and Environmental Science, 90(1) (2017) DOI: 10.1088/1755-1315/90/1/012049

19. A. Armisena, A. Majchrzak. Business Horizons, 58(4), 389-399 (2015) DOI: 10.1016/j.bushor.2015.03.004

20. G. Morunova, S. Gorbushina, V. Okrepilov, S. Kuzmina. MATEC Web of Conferences, 239, 08005 (2018) DOI: 10.1088/1757-899X/497/1/012134

21. K. Buka-Vaivade, J. Sliseris, D. Serdjuks, L. Pakrastins, N.I. Vatin. Magazine of Civil Engineering 84(8), 3-14 (2018). DOI:10.18720/MCE.84.1.

22. C. Campian, N. Chira, V. Iuhos, M. Pop, N. Vatin. Procedia Engineering 165, 876-882 (2016). DOI:10.1016/j.proeng.2016.11.787.

23. V. Goremikins, K. Rocens, D. Serdjuks, L. Pakrastins, N. Vatin. Advances in Civil Engineering and Building Materials IV - Selected and Peer Reviewed Papers from the 2014 4th International Conference on Civil Engineering and Building Materials, CEBM 2014. 2015. Pp. 363-368.

24. V. Goremikins, D. Serdjuks, K. Buka-Vaivade, L. Pakrastins, N. Vatin. Baltic Journal of Road and Bridge Engineering. 2017. 12(4). Pp. 234-240. DOI:10.3846/bjrbe.2017.29.

25. A. Gorshkov, N. Vatin, D. Nemova, A. Shabaldin, L. Melnikova, P. Kirill. Procedia Engineering. 2015. 117(1). Pp. 1080-1089. DOI:10.1016/j.proeng.2015.08.240.

26. A. Gorshkov, N. Vatin, D. Nemova, D. Tarasova. Applied Mechanics and Materials. 2014. 633-634. Pp. 897-903. DOI:10.4028/www.scientific.net/AMM.633-634.897. 